\title{
The Picketing in Turkish Labour Law
}

\author{
Merda Elvan Tunca \\ PhD, Pamukkale University, Faculty of Law, Denizli, Turkey
}

\begin{abstract}
The Collective labour disputes between the employee and the employer parties, during negotiations to conclude a collective labour agreement, can be resolved through peaceful and combative ways. Strike is a combative method that employees leave their work or disrupt their activities in the workplace in order to improve their working conditions economically or obtain new rights. If there is a strike which fulfils the conditions of a lawful strike regulated in the Law No. 6356 on Trade Unions and Collective Bargaining Agreement, there will be a lawful strike. The second type of strike which is the unlawful strike; is any strike that happens without fulfilling the conditions of a lawful strike. Picketing is also a combative method that is applied to solve the collective labour disputes in labour law, and has an importance within the freedom of expression. In daily language; picketing is defined as a personal or collective protest by using banners against an event or a person. In terms of labour law; picketing is defined as employees gathering at the entrance of their workplace while there is an ongoing strike, in order to complain about the employer to the other employees and to the society, and also to persuade the other employees to leave their jobs and join the strike. The aim of this study is to examine the concept of picketing in terms of Turkish labour law by comparing with the Anglo-Saxon law.
\end{abstract}

Keywords: picketing, Turkish, labour, law

\section{Introduction}

The existence of industrial action is important in the development of relations between employee and employer in the history of labour law and is one of the basic concepts of labour law. Industrial action, which remained on an individual level until the industrial revolution, has continued with collective labour movements after this revolution. The unions are the main actors of an industrial action. The unions especially organized to protect employees' rights collectively, directly contribute to the development and maturation of fundamental rights. The unionism movement is an actor that plays a prominent role in the birth and settlement of the contemporary understanding of freedom. The unions are the pioneers and guards of the rights that employees have and the rights that they will gain in the future. An independent unionism movement and modern democracy are complementary parts. In a free and democratic environment, unions are the protectors of both economic and social rights and classical fundamental rights and freedom (Kapani,1993:278).

The strike is a right that is considered within the union right. In addition, the right to strike is linked to the right of assembly and protest marches. The right of free speech and the right of assembly and protest march are directly linked especially in terms of "picketing".

Disputes arising from labour law may arise in legal relations between the employee and the employer in working life. The conflict between a single employee and employer is an individual labour dispute and a conflict between a employee union and an employer union or an employer is a collective labour dispute (Tunçomağ and Centel, 2018:419; Demir, 2018:703). The collective labour dispute has two sides. There is a trade union on the one hand and an employer or an employer union if the employer is a member of the union. The conflict between these parties to improve or change working conditions is collective labour dispute (Tunçomağ and Centel, 2018:419).

The collective labour dispute is about the regulation of working conditions such as working time and wages, such disputes are called collective right disputes (Tunçomağ and Centel, 2018:419). Conflicts arising from obtaining a new right or interest and making arrangements for a new right are called conflict of interest (Demir, 2018:704). Collective conflict of interest is the result of a conflict of interest in sharing the production income between capital and labour (Narmanlığlu, 2013: 499). Collective rights dispute arises due to the improper enforcement of the provisions of the legislation and collective agreement 
between the parties (Tunçomağ and Centel, 2018:420; Demir, 2018:704). Rights disputes arise from not granting or violating a right regulated in the sources of labour law (Tuncay and Kutsal, 2015: 314). In Turkish labour law, disputes of rights are resolved by courts or arbitration.

In Turkish labour law, the resolution of collective conflicts of interest is done in peaceful and combative ways. Peaceful ways are mediation, reconciliation and arbitration. The main combative solutions are strikes and lockouts. However, a peaceful solution must first be applied for a legal strike in Turkish law. There are other combative methods in the labour world besides the strikes applied by the employees. Boycott, picketing and blacking are examples of this (Tuncay and Kutsal, 2015: 315).

The word "strike" in Turkish law comes from French; the word "strike" was used in the first Labour Act No. 3008, which came into force in 1937, and "the strikes" were prohibited by this Act (Sur, 1987: 7). Collective labour disputes arising during the Act no. 3008 were resolved through mediation and compulsory arbitration (Çelik et al., 2017: 936).

The strike is the resistance of a professional group to leave a job against a situation or decision in sociological terms (Sur, 1987: 7). The strike is an economic pressure tool for the employer. The strike has the aim of influencing the will of the employer and putting pressure on the employer to improve the working conditions in the workplace (Narmanlıoğlu, 1990: 6). Strike is a employees-specific bargaining tool (Sur, 1987: 2). The strike is a method that employees use to improve their running conditions, but the strike may have other purposes. The strike is a fact that also completes the democratic process and the employees who apply to the strike have the opportunity to express their views and make their voices heard (Narmanlığlu, 2013: 534).

Apart from strikes, employees can also apply to other means in order to have the employer accept their requests. Employees also want to use pressure tools other than the usual and known methods to reduce the negative effects of the strike on themselves. It is important whether the repression tools are important or not rather than strike (Narmanlığlu, 2013: 682). If the method to be applied against the employer is not legal, the employee will have to bear the consequences of the illegal strike. If the method that the employees apply collectively is legal, employees' industrial action will be protected by law. The right to strike in Turkish law is a right where the intervention of the state is intense. The Trade Unions and Collective Labour Agreement Act No. 6356, which came into force on 7 November 2012, is the basic law that regulates the right of employees to establish unions, to contract collective labour agreements and to strike. This Act has been criticized by Özveri (2012) for taking the state's interfering approach to the right to strike. Act No. 6356 extends the scope of the illegal strike, causing illegal acts of employees. (Özveri, 2012: 164).

Picketing is also a kind of economic pressure on the employer, such as strike. This industrial action as described below (Teller, 1942: 201):

"Picketing is the marching to and fro before given premises with a banner usually containing assertions that the picketed person is " unfair to organized labor," or that his employees are on " strike".

The number of the strikes is dramatically decreasing in Turkey. It is declared that the number of annual strikes between 2001-2015 decreased by 85 percent compared to the period 1985-2000 (www.bianet.org).

The effecacy of the strikes is discussed due to the decrease of the number of the strikes in USA (Rachleff, 2003:87). Picketing has a function that it is informational and designed to publicize the fact that a dispute exists with the employer (Twarog, 2006: 9).

The employees need more industrial action ways to express their opinions, especially about working conditions. The problem is that of which the industrial actions shall be assumed legal or illegal. The legal ways of industrial actions shall be protected by the law. But the illegal industrial actions will come across the sanctions of the law. The labour contracts of the employees who join the illegal industrial actions can be terminated by the employer without any compensation.

\section{The Concept of Industrial Action}

Collective industrial action is the resolution of collective labour disputes by the help of collective actions in the resolution of collective labour disputes. Peaceful solutions are not included in the collective industrial action concept (Tuncay and Kutsal, 2015: 315). 
The concept of industrial action in Turkish law includes concepts such as strike, lockout and boycott (Tunçomağ and Centel, 2018:437). Picketing and blacking are also among the combative methods (Tuncay and Kutsal, 2015: 315). Blacking is the refusal of employees to perform a job or an order from the employer (Tuncay and Kutsal, 2015: 315).

Industrial action is the way employees or employers seek to put pressure on the other party and have their wishes adopted in order to achieve a specific purpose by following a given decision of struggle. Parties to industrial action are the community or organization of employees or employers. The reason why industrial action on the employees' side is collective (Tunçomağ and Centel, 2018:437) is because the employees are economically and socially weak against the employer on the employee's side (Ertürk, 1999: 6,8). One employee cannot be a party to industrial action (Tunçomağ and Centel, 2018:437).

Industrial action, which aims to change and improve working conditions, is among the subjects of labour law. The feature of industrial action in labour law is that it is challenging and repressive (Ertürk, 1999: 21,24). In industrial action, the peace of working with mass movement should deteriorate and a certain purpose should be found. The aim of the employee and employer's side in industrial action is to eliminate a collective conflict. The aim of both sides of this struggle is to continue the legal relationship between them.

Parties explain their wishes and thoughts in non-repressive business struggles having the characteristic of warning, condemnation and demonstration (Ertürk, 1999: 24).

\section{Strike and Boycott}

The strike is a primary expression of working people's power since the emergence of wage labor and industrial capitalism some 200 years ago (Rachless, 2003:87). The lexical meaning of "strike" is "employees connected to a workplace collectively quit their own will and don't work" (Narmanlıoğlu, 1990: 5). The strike is quitting the job that is applied by the employees to obtain their requests and it causes the employment contract to be temporarily not applied. (Tunçomağ and Centel, 2018:450).

The reason for the employees to use the strike as a pressure tool is to improve their working conditions. Employees strike with requests such as increasing wages, regulating working times, increasing rest periods and increasing compensation amounts (Tunçomağ and Centel, 2018:462). Although the strike is an economic pressure tool, the strike has other purposes. The aim of the strike is to defend trade union rights and freedoms, to defend employees' rights in the workplace and to correct the economic and social policies implemented (Narmanlıoğlu, 1990: 7).

Strike is one of the industrial action tools that provide and protect employees' benefits to employers (Narmanlıoğlu, 1990: 5) and it is an industrial action method that only employees can apply (Tunçomağ and Centel, 2018:452). Two basic elements are necessary for the presence of the strike. The first element is the cessation of a job, which is the characteristic feature of the strike (Tunçomağ and Centel, 2018:452). Although the boycott is also an industrial action mediator, this element is not present in the boycott (Narmanlıoğlu, 1990: 52,61; Ertürk, 1999:31).

Strikes in the world can occur in many ways in working life. Examples include sitting strikes, partial strikes, alternately strikes, zealotry strikes, sympathy strikes, political strikes, general strikes and key personnel strikes. These striking actions are considered illegal strikes if they do not meet the definition of a legal strike in a country (Tuncay and Kutsal, 2015: 316).

The boycott, which is not a typical industrial action, is an aid to strike and lockout (Ertürk, 1999:31,56; Tunçomağ and Centel, 2018:440). A boycott is when a community of people interrupts their social or economic relationship with the person or persons they set up, following a plan. Economic relations are broken up and the market areas of these people are narrowed. However, the strike does not aim to weaken the person boycotted economically (Sur, 1987: 11; Tunçomağ and Centel, 2018:441). Boycott is a way of social reaction outside of working life (Ertürk, 1999:55). Boycott action can also be applied in business life (Tuncay and Kutsal, 2015: 318) In terms of labour law, the boycott requires the presence of the organized employee and employer side and must be of a nature that supports the strike or lockout (Ertürk, 1999:57).

Employees on the strike stop working for specific purposes while their employment contracts continue (Sur, 1987: 13). The quitting of the job, described as the material element of the strike, must be voluntary and in a collective decision (Narmanlıoğlu, 1990: 52,61). In order for a job cessation to become a strike, those who leave the job must have the right to strike legally and quitting the job should aim to halt or substantially disrupt business activity (Narmanlıoğlu, 1990: 54). Quitting the job means that the employees who stopped the job and participated in the strike left the workplace. If the 
employees just quit the job without leaving the workplace, like sit-in-protest, it is not considered a legal strike (Çelik et al., 2017: 949).

The second element is that there is an agreement to quit the job or the decision of a employees' organization (Narmanlıoglu, 1990: 50,77; Tunçomağ and Centel, 2018:454).

\section{Right to Strike}

In the category of rights, the right to strike is handled within the right to welfare. The reason for this is that the right to strike is aimed at improving the social situation of individuals or groups or increasing their welfare (Erdoğan, 2016: 274).

The right to strike is a social right exercised through unions (Narmanlıoğlu, 1990: 11-12; Ertürk, 1999:206) and it has the nature of balancing the economic power of the employer against the employees (Sur, 1987: 2). The aim of the right to strike is to reduce social inequality, protect people who are economically weak and ensure social justice (Narmanlıoğlu, 2013: 539). The right to strike includes the employee being able to quit his job duly with other employees, avoiding work during the strike, and resuming at the end of the strike (Narmanlığlu, 2013: 535). One of the main features of the right to strike is that it has an inalienable right (Narmanlıoğlu, 2013: 540).

The right to strike is one of the most important basic rights of the employees in a democracy understanding that develops over time and takes into account social rights (Narmanlıoğlu, 1990: 8; Demir, 2018:709). The right to strike must be used within the legal rules (Narmanlıoğlu, 1990: 9). The right to strike, which is used in accordance with the legal rules, gives the employee the right to quit his job and the employer cannot terminate the employee's employment contract due to absenteeism (Narmanlıŏlu, 2013: 535).

The right to strike is a right granted to both employees and trade unions. The right to strike cannot be exercised individually by a single employee. The right to strike should be used collectively by the labour union decision. Therefore, the right to strike is also a distinctive right (Narmanlıoğlu, 2013: 537).

The right to strike was regulated in Turkish law for the first time in article 47 of the 1961 constitution as a constitutional right. The right to strike was included in the third part that regulates social and economic rights and duties. According to Article 47 of the 1961 Constitution, employees had the right to strike. According to the reasoning of Article 47, the right to strike is a right enforced by the democratic order. In the 1982 Constitution, which came into force after the 1961 Constitution, the right to strike was regulated under the title of social and economic rights and duties. According to Article 54 of the Constitution, employees have the right to strike. Therefore, public officers do not have the right to strike. According to the Constitution, the right to strike can only be regulated by Act. The 1982 Constitution regulated the right to strike in detail, but in the article regulating the right to strike in the constitution, the right to strike is narrower than the 1961 constitution (Sur, 2012: 163).

It is important to identify the action to be covered by the right to strike. Because actions that fall under the scope of a legal strike benefit from the protective provisions of a legal strike. In this respect, it is important whether or not "picketing" will be considered in the context of a legal strike in Turkish law.

The right to strike has the same and inseparable objectives as the right to union, the right to collective agreement, and there is a close-knit relationship between all these rights. The absence of one right in collective social rights makes it impossible to use another (Narmanlıoğlu, 1990: 14; Özveri, 2012: 162). Therefore, rules restricting the right to strike negatively affect the right to union and the reasons for function and existence of the unions (Narmanlıoğlu, 1990: 17).

\section{The Unions and Collective Bargaining Agreements Act No. 6356 That Regulates the Employees' Right to Strike}

Act No. 6356 is an act regulating the collective labour relations abolished the Trade Unions Act No. 2821 and Collective Labour Agreement, Strike and Lockout Act No. 2822. The Act No. 2821 and Act No. 2822 had been amended many times since the date of their enforcement on 7 May 1983 to extend trade union rights. Act No. 6356 is a law that regulates the union rights of employees as a rule. The definition of the employee concept was not made in the act, and reference is made to the Labour Act No. 4857 for the definition of the employee. In Labour Act No. 4857, which is a basic law that regulates individual business relations in Turkish labour law, the employee is defined as a real person working on the basis of an employment contract. In addition to the Labour Act No. 4857, there are also employees working under the Press Labour Act, the Maritime Labour Act and the Act of Obligations. All employees working under the laws in force in Turkish 
labour law are included in the Act No. 6356. Besides, the Act No. 6356 also counted the real persons who independently carry out professional activities outside the employment contract to carry on working for a fee, according to the contract of work, power of attorney, publication, commission and unlimited company agreement. However, these employees, who are deemed as employees, have the right to establish trade unions and to become members of a union in Act No. 6356. Only employees' unions have the right to conclude collective labour agreements and strike regulated in Act No. 6356. Other employees" unions that the Act No. 6356 counts as employees are not entitled to conclude collective bargaining agreements and to strike.

\section{Legal Strikes and Illegal Strikes in Turkish Labour Law}

There is a distinction between legal strike and illegal strike in Law No. 6356. The strike is defined as follows in the law: "The employees leave the job by agreeing among them or following an organization's decision not to work collectively for the same purpose in order to stop the activity in the workplace by collectively not working or to disrupt it significantly according to the nature of the work" (article 58/l).

The first condition for a legal strike is that it was done at a work or workplace that is not covered by the prohibition of strikes ${ }^{1}$ (Tunçomağ and Centel, 2018:461). The second element of the legal strike is that the strike can only be carried out for certain purposes. This purpose, which is named as professional purpose, (Tunçomağ and Centel, 2018:462) is only to protect and improve the economic and social conditions of employees and working conditions. A legal strike decision can be made at the time of collective agreement negotiation. Strikes to resolve conflicts of interest that arise in collective agreement negotiations will have the nature of a legal strike (Tunçomağ and Centel, 2018:462). According to Article 54 of the Constitution, which regulates the right to strike and Article 58 of Law No. 6356, there must be a dispute for the existence of a legal strike during the "collective agreement negotiations". The area of recognition of the right to strike in the Constitution is set and limited in a certain framework. However, these limits can be extended by law (Sur, 2012: 165). According to Erdogan (2016), the right to strike can also be used for disputes that are not related to collective agreements. Law 6356 also regulated the rules of the form of a legal strike in detail. A strike contrary to these rules will not be a legal strike.

In order to take a legal strike decision, it is compulsory to pass the mediation stage, which is a peaceful solution, as required by Act No. 6356. The parties to the collective agreement negotiation cannot decide not to apply to the mediator (Narmanlıoğlu, 2013: 506). Mediation in Turkish law is a service provided by the Ministry of Family, Labour and Social Services and affiliated provincial directorates. The mediator is officially appointed and takes formal action. The mediator is the person who strives for the agreement of the parties to the collective agreement, but the mediator's proposals are not binding for the parties. If the mediator cannot provide the agreement of the parties of the collective agreement, he prepares a mediation report and this report is notified to the parties (article 50). Within 60 days from the notification of this minutes, the authorized labour union can take a strike decision and determine the date of the strike. The strike must have started within a 60-day period. In the calculation of this period regulated by the law, the calendar day is calculated and (Tunçomağ and Centel, 2018:465). The strike start date is reported to the employer or employer union by the authorized trade union, which is the other party to the collective labour dispute. The strike start date may be at least six working days from the date of this notification. The authorized labour union loses its power to conclude collective agreements, if the law does not

\footnotetext{
1 The prohibitions of strikes and lockouts are regulated hereinbelow (Art. 62 of Act No. 6356):

(1) It shall not be lawful to call a strike or order a lock-out in the following works: Life or propertysaving, funeral and mortuary, production, refining and distribution of city water, electricity, natural gas and petroleum as well as petrochemical works, production of which starts from naphtha or natural gas; banking services; in workplaces operated directly by Ministry of National Defence, General Command of Gendarmerie and Coast Guard Command, fire fighting and urban public transportation services carried out by public institutions and in hospitals.

(2) Where the life of the community is paralysed by natural disaster, the Council of Ministers may prohibit strikes and lock-outs in the workplaces located in such areas as may be necessary, provided that it will be effective for as long as the situation continues. The strike and lock-out shall be implemented within sixty days after the prohibition is lifted, provided that the opposite party is informed six working days beforehand.

(3) It shall not be lawful to call a strike or order a lock-out in sea, air, rail and road transportation vehicles, which have not finalised their journey in places of domestic destination.
} 
decide to strike within the 60-day period, does not inform the other party of the strike start date or does not start the strike on the reported strike start date.

A legal strike is defined in Article 58 of Law No. 6356. In the justification of Article 58, general strikes, political strikes and solidarity strikes, and slowing down work, reducing productivity, and other resistance not being regulated by law would not cause these actions to be legal. There is no regulation that gives the right to carry out these actions and boycotts or that makes them lawful (Demir, 2018: 710; Sur, 2012: 166; Kaya, 2013: 151).

\section{The Concept of Picketing}

Picketing is a kind of industrial action applied mostly in the countries where Anglo-Saxon Law is applied. There are many articles discussing the dictums of the courts about picketing in USA, Great Britain (Vorspan, 1998: 593) and, Canada. The legal frame of the union rights is different in England from USA (Vorspan, 1998: 593).

Picketing is also a kind of economic pressure on the picketed employer, such as strike. It has also relationship with the boycott. Because, picketing is a physical activity in the nature of a parade or procession engaged in as part of a boycott, at the beginning of 1900's, the practice of picketing had been seen, that picketing was a tort (Teller, 1942: 202, 204). Besides, picketing is not always used as an industrial action. A type of picketing called informational picketing is a public, visible demonstration that takes place usually in front of the hospital or facility where the dispute occurs. During picketing, the group of employees gather together and, hold signs and who walk along the property line in front of the facility. The participants of picketing often chant or sing as they walk and, also the non-employees participants can participate the picketing (Twarog, 2006: 9).

A clue to the concept of picketing can be found in a decision enacted in 1937 in USA law. In this decision, it was accepted that union members would make the facts known within the scope of freedom of expression. Picketing is a concept that has meaning from different perspectives. The most important feature of this concept is that it is under constitutional protection in USA law. The word picketing was used in 1956 for a protest in front of the Russian embassy in the USA. Banners were used in this protest, and the media used the word "Picketing" for this action. However, such actions not including employees' organizations are not considered picketing (Forkosch, 1957: 391). The protest of a single person carrying a banner is not counted as picketing (Forkosch, 1957: 394).

The first element required for picketing is about where this action is done. The employer's own employees' picketing in the workplace is "primary picketing". Secondary picketing, on the other hand, is the picketing faced by other entrepreneurs with whom the main employer is wanted to put strain on. Picketing needs to be done for the workplace of the employer who is intended to put strain on (Forkosch,1957:397).

If the picketers seek to organize the employees of the picketed employer, that is, organizational picketing;' or economically to coerce the employer into signing a contract; or to inform the public or the employees, or both, of the facts in the situation, that is, informational picketing; or to educate the employees of the benefits to be derived from joining the union, that is, educational picketing (Forkosch, 1957:398). For a peaceful picketing, a strike by a union must exist (Teller, 1942: 186). In a dictum in 1941 had been stated that that peaceful picketing could not constitutionally be enjoined even though it was carried on by a union in the absence of a labour controversy between the picketed employer and his employees (Teller, 1942: 186).

During the picketing, the picketer does not need to speak, and yet his placard and his presence speak for him (Forkosch, 1957:404).

The elements of pure picketing are (Forkosch, 1957:407):

"pure picketing may involve a fact situation in which one or more individuals, uttering no slanders, imprecations, or untruths, carrying a reasonably-sized placard or sign and perhaps handing out throw-aways which likewise contain no untruths, walk not too slowly or rapidly to and fro in front of the employer's place of business, without blocking traffic, causing any congestion, or otherwise creating a disturbance, for a purpose or end which is not coercive, does not coerce, and does not seek primarily to injure anyone, is not to compel anyone to break any laws or obligations, and is to obtain benefits for the picketers or their principals, factually or legally, directly or indirectly". Only this type of picketing will be protected by the constitution of USA. Pure picketing will be protected in the scope of free speech. 
Picketing is also an economic pressure method that is among the industrial action methods. In everyday language, it means that soldiers patrolling up and down in a particular area. In the concept of picketing as a collective industrial action method, employees gather in front of the workplace entrance and carry a banner in their hands. In the banners, the employees write down their requests and try to get them accepted by the employer. Another aim of the employees participating in picketing is to persuade the employees who did not participate in the strike (Tuncay and Kutsal, 2015: 319).

According to Isaacson, there are two types of picketing (1959: 347) Organizational picketing is the picketing by a minority directed to employees in order to persuade them to become union members or to win their adherence to the union cause. The second type of picketing -Recognition picketing- is a picketing directed to an employer in order to compel recognition of a minority union-to bring pressure on an employer to bring pressure on the employees to join a picketing union.

Picketing is an industrial action method seen in Anglo-Saxon law, and this concept plays an important role in industrial action law. The picketing done by the participants of the strike against those who are willing to work during the strike is called peaceful picketing (Junker, 2010:27).

Picketing is a pivotal labor tactic that employees embraced as their most powerful and weapon The Word "picketing" was first used in a legal sense in 1867 in England. The word referred to men stationed by a trade union outside an employer's premises to publicize a strike and persuade employees not to work. Picketing has an important role during strikes. It is the significant factor which determines the success or failure of strikes (Vorspan, 1998: 596).

Picketing is not a legal industrial action method due to the legal strike definition of Law No. 6356 in Turkish Labour Law. Therefore, the action of employees participating in the picketing action will be considered an illegal strike in Turkish law (Tuncay and Kutsal, 2015: 319).

The behaviours related to the abandonment of the job, which does not have the phenomenon of quitting the job completely or not carried out with the intention of a strike, are not considered as a strike. These actions, which do not have the nature of a legal strike, are considered illegal strikes (Narmanlığlu, 2013: 684). Due to the definition of legal strike in Law No. 6356 , employees' actions that do not carry the elements of the legal strike will also be considered illegal. The action of employees to quit their collective work without a union decision has the nature of an illegal strike. Law No. 6356 abolished employees' right to collective action in other cases, except in case of a dispute during the conclusion of the collective agreement (Özveri, 2012: 165).

\section{Strike Pickets in Turkish Labour Law}

The concept of picketing in Turkish labour law has a different meaning in the Act of No. 6356. According to Article 73 of Act No. 6356, the labour union that has declared a strike at the workplace can employ a strike-picket to ensure compliance with a legal strike decision and without threats. Strike-pickets can only be appointed by the competent union in the presence of a legal strike. Strike-pickets are selected from employees who are members of the authorized trade union. Strike-pickets cannot prevent entry and exit from the workplace and stop the people to control those entering and leaving the workplace.

In the Collective Bargaining Agreement Strike and Lockout Act No. 2822, which was in force before the Act No. 6356, it was forbidden to hang noticeboards such as posters and banners, except for the phrase "There is a strike in this workplace". It was decided that shelter vehicles such as huts, sheds and tents cannot be established for strikers or strike-keepers in and around the workplace by the employees or the trade union. (Article 48 / II, III). These bans have been lifted in Act No. 6356.

\section{Conclusion}

In the labour history in Turkey, strikes were forbidden and, deemed as a tort-crime at the first decade of the 20th century. The Constitution of 1982 regulates the right to strike as a constitutional right. The right to strike is regulated by the Act No. 6356 only for he employees. In Turkish law, the public officers do not have the right to strike constitutionally. In Turkish labour law, the definition of the strike is limited by the Act and, only the legal form of the strike is assumed "legal strike". Other forms of strikes or any industrial action shall be deemed as illegal.

The doctrine in constitution law regards other forms of industrial actions legal in the scope of the constitutional rights, especially in the scope of free speech. On the contrary, by the doctrine in labour law using the positive sources of labour law, the industrial actions which are not in the form of legal strike deemed as illegal. 
In Anglo-Saxon law countries, the concept of picketing has been discussed by the doctrine and, the courts from the end of the 19th century. Strike was a crime or a tort activity at the beginning of its implementation in the history. Picketing was described as a tort activity by some USA courts during the first half of the 20th century.

Most of the picketings are related to the labour, some of them not. Whatever the picketing is related to, the most high point of picketing is being the core of the free speech. The labour life, the improvement and implementation of social rightsunion rights- is directly affected by the existence of democracy understanding in a country. According to the regulations in Turkey, a picketing during a strike shall be deemed as an illegal strike.

\section{References}

[1] Antoine, T. J. St., (1982), "Free Speech or Economic Weapon? the Persisting Problem of Picketing", Suffolk Law Review, Vol. Xvi, N. 4, 883-906.

[2] Çelik, N., Caniklioğlu, N., Canbolat, T., (2017), Iş Hukuku Dersleri, İstanbul: Beta.

[3] Demir, F., (2018), Iş Hukuku Ve Uygulaması, İzmir: Birleşik Matbaa.

[4] Erdoğan, M., (2016): Insan Hakları Teorisi Ve Hukuku, Ankara: Orion.

[5] Ertürk, Ş.(1999), İ̧ Mücadelesinde Denge Illkesi, İzmir: Dokuz Eylül Üniversitesi Hukuk Fakültesi Döner Sermaye İşletmesi.

[6] Forkosch, M. D., (1957), An Analysis and Re-Evaluation of Picketing in Labor Relations, Fordham Law Review, Vol. 26, Issue 3, 391-440.

[7] Isaacson, W. J. (1959), Organizational Picketing: What is the Law?-Ought the Law to Be Changed? Buffalo Law Review, Vol. 8, N. 3, 345-370.

[8] Junker, a., (2010), Entwicklung Des Arbeitskampfrechts in Europa, 7. Zaar-Kongreß „Neues Arbeitskampfrecht?,München.

[9] Kapani, M., (1993), Kamu Hürriyetleri, Ankara: Yetkin.

[10] Kaya, P.a., (2013), Uluslararası Normlar Bağlamında Sendikalar Ve Toplu İş Sözleşmesi Kanununun Değerlendirilmesi, Sosyal Haklar Uluslararası Sempozyumu, 131-155

[11] Narmanlioğlu, Ü., (1990), Grev, İzmir: Dokuz Eylül Üniversitesi Hukuk Fakültesi Döner Sermaye İşletmesi.

[12] Narmanlioğlu, Ü., (2013), İş Hukuku li Toplu İş ilişskileri, İstanbul: Beta.

[13] Özveri, M., (2012), Sendikal Haklar, İstanbul: Birleşik Metal İ̧̧ Yayınları.

[14] Rachleff, P., (2003),"is the Strike Dead?" New Labor Forum, Vol. 12 Iss. 2, 87-94.

[15] Sur, M., (1987), Grev Kavramı Türk Ve Fransız Hukuku Açısından Karşılaştırmalı Inceleme, İzmir: Dokuz Eylül Üniversitesi Yayınları.

[16] Sur, M., (2012), 6356 Sayılı Sendikalar Ve Toplu İ̧̧ Sözleşmesi Kanununda Grev Hakkı, Sicil, 163-171.

[17] Teller, L., (1942), Picketing and Free Speech, Harvard Law Review, Vol. 56, No. 2, 180-218.

[18] Tuncay, a.C., Savaş Kutsal, B.,(2015), Toplu İş Hukuku, İstanbul: Beta.

[19] Tunçomağ, K., Centel, T. (2018), Iş Hukukunun Esasları, İstanbul: Beta.

[20] Twarog, J., (2006), "Informational Pickets, Rallies, Vigils and Leafleting at Health Care Facilities", Massachusetts Nurse.

[21] Vorspan, Rachel (1998), "the Political Power of Nuisance Law: Labor Picketing and the Courts in Modern England, 1871-Present", Buffalo Law Review, Vol: 46, N. 3, 593-703. 